\title{
Historical Institutionalism in Rationalist and Sociological Perspective
}

\section{Citation}

Hall, Peter A. "Historical Institutionalism in Rationalist and Sociological Perspective." In Explaining Institutional Change: Ambiguity, Agency, and Power. New York, NY: Cambridge University Press, 2010. doi: 10.1017/cbo9780511806414.009

\section{Published Version}

10.1017/cbo9780511806414.009

\section{Permanent link}

http://nrs.harvard.edu/urn-3:HUL.InstRepos:34298769

\section{Terms of Use}

This article was downloaded from Harvard University's DASH repository, and is made available under the terms and conditions applicable to Open Access Policy Articles, as set forth at http:// nrs.harvard.edu/urn-3:HUL.InstRepos:dash.current.terms-of-use\#OAP

\section{Share Your Story}

The Harvard community has made this article openly available.

Please share how this access benefits you. Submit a story.

\section{Accessibility}




\title{
Historical Institutionalism in Rationalist and Sociological Perspective
}

\author{
Peter A. Hall \\ Minda de Gunzburg Center for European Studies \\ Harvard University \\ 27 Kirkland Street \\ Cambridge MA 02138 \\ phall@fas.harvard.edu
}

Forthcoming in James Mahoney and Kathleen Thelen, eds., Explaining Institutional

Change: Ambiguity, Agency. Power (New York, Cambridge University Press 2009). 


\section{Historical Institutionalism in Rationalist and Sociological Perspective}

Peter A. Hall

Some of the most fruitful insights generated by social science in recent decades flow from explorations of how institutions, understood as sets of regularized practices with a rule-like quality, structure the behavior of political and economic actors. ${ }^{\mathrm{i}}$ It is not surprising that attention has now turned to the second-order problem of explaining when and how institutions change. ${ }^{\mathrm{ii}}$ In conceptual terms, however, this task is intrinsically difficult. By their nature, analyses designed to explain why institutions have a persistent impact on behavior tend to overstate the solidity of institutions. Acknowledging their plasticity raises questions about when institutions should be seen as determinants of behavior and when objects of strategic action themselves. ${ }^{\text {iii }}$

This problem afflicts rational choice approaches to institutions with particular intensity because of the elegant solutions such analyses have devised to explain the force and persistence of institutions. Typically, they see institutions as patterns of regularized behavior that reflect Pareto-optimal equilibria or sub-game perfect solutions to collective actions dilemmas, stable because none of the actors can improve his position by defecting 
from the pattern of behavior (Greif and Laitin 2004, Koremenos et al. 2003, Shepsle 1989). Therefore, institutional change happens only when ceteris is no longer paribus, i.e. when shocks exogenous to the system of institutions itself alter the context. Institutional change becomes a response to shocks. Such analyses posit a radical separation between periods of institutional stability and of change (often labeled 'critical junctures') that rarely explain well how institutions emerge from disequilibrium at such junctures (see the Introduction to this volume and Thelen 2004). ${ }^{\text {iv }}$

As the essays in this volume indicate, approaches associated with 'historical institutionalism' are more attentive to problems of institutional change. They offer correctives to dualist views that separate periods of institutional stability and change, noting that institutional change can be continuous and institutional transformation the product of incremental adjustment (Streeck and Thelen 2005, Palier 2005). They are sensitive to the power relations associated with institutional change and inclined to accord belief-systems a role in such processes (Moe 2005; McNamara 1998). For these reasons, analysts often draw a sharp distinction between rational choice and historical institutionalism.

This essay takes a different approach to the problem. Rather than emphasize the differences between rational choice and historical institutionalism, I explore the common 
ground between them, asking how the insights of the latter can be used to improve the former. The motivation is straightforward. In my view, rational choice approaches to institutions offer some powerful insights into the operation of institutions. The problem is that they do not yet carry over into an effective analysis of institutional change. My solution is to broaden the rationalist model slightly and to build into it some of the key insights offered by historical institutionalism. In short, this is an attempt to show that historical institutionalism has much to offer rationalist analysts of politics and to suggest that models of institutional change which integrate propositions from both research traditions are not only possible but promising. The result is a research agenda well worth pursuing.

In the first part of this chapter, I make that case by outlining the core propositions of a model of institutional change that is recognizably rationalist. I then identify some of the problems left unresolved by that model and draw contentions from historical institutionalism that offer potential solutions to these problems. The objective is to identify a chain of variables affecting the pace and direction of institutional change that are plausible targets for empirical research. I cannot test the model here against empirical cases, but I reference research bearing on some of its propositions.

However, there are also clear limits to rationalist models of institutional change. 
The world of institutions is more multifaceted than such models allow, and one of the virtues of historical institutionalism is that it sees this other world as well. In short, there is a second side to historical institutionalism - at its interface with sociological approaches to institutions - that reveals further dimensions of the institutional world and alternative routes to institutional change. These too deserve a place on contemporary research agendas. Accordingly, in the second part of this chapter, I look briefly at the other side of historical institutionalism, with a view to highlighting its distinctive contributions to analyses of institutional change.

Scope conditions are an issue for all arguments about institutional change (MacIntyre 1978). We do not yet know whether the relevant processes in legislatures, firms, universities, electoral arenas and political economies are similar enough to be described by a common model of institutional change. Accordingly, the propositions I advance are designed to bear on the political economy, although many may apply more generally.

\section{A Rationalist Model of Institutional Change}

With that prologue, I turn to the task of outlining some of the key features of the process of institutional change when seen in rationalist perspective. 


\section{Rules and Coalitions}

The problem of explaining the timing, shape and direction of institutional change can usefully be treated, in the first instance, as a matter of outlining the coalitions of actors, whether individuals or social groups, who line up in favor of (or against) a particular shift in rules or practices and of explaining why the actors take the positions they do. This is a plausible starting point with wide resonance in political science. The premise is that institutional change is best understood by integrating coalitional with institutional analysis. $^{\mathrm{v}}$

This coalitional approach has a nice affinity with rational choice analyses that see legislative rules, such as those governing agenda-setting and decision-making, as the basis for a 'structurally-induced equilibrium' that prevents the constant cycling of coalitions about policy issues that Riker (1980) suggested we could otherwise anticipate, given Arrow’s impossibility theorem (Shepsle 1979; Marshall and Weingast 1988). The key question, of course, is why there is not analogous cycling over the institutional rules themselves. Why do legislative institutions remain relatively stable? ${ }^{\mathrm{vi}}$

\section{Uncertainty and Instrumental Beliefs}


Institutional stability is a foundational issue for analyses of institutional change. In order to understand change, we must be able to explain, in parallel terms, stability. For legislative institutions, Shepsle (1986) provides a crucial component of the answer, in the form of a 'wedge of uncertainty'. The ultimate impact of adopting new institutional rules is often, as he observes, hard to predict. Accordingly, even if actors could enact a substantive measure that they favor by changing those rules, they may hesitate to do so, lest the new rules disadvantage them during the consideration of other issues that are difficult to anticipate. This point is widely applicable to analyses of institutional change. Uncertainty is a central feature of politics. Where it is high enough to interfere with the actors' calculations of how they will fare under alternative institutional arrangements in a range of possible futures, they may prefer the status quo to change.

However, this is also the initial point at which the insights of historical institutionalism can be used to enrich the analysis. The level of uncertainty about the impact of proposed institutional changes turns, at least in part, on the availability of what might be described as 'instrumental beliefs', namely means-ends schemas that describe in this instance how the adoption of new institutions will affect the likelihood of achieving various types of goals, as well as on the level of confidence with which such beliefs can be held. The character of prevailing instrumental beliefs is a key ingredient in the 
processes of coalition formation that underlie institutional reform (Krehbiel 1991, Goldstein and Keohane 1993, Hall 1989).

Common sources for such beliefs include communities of relevant experts and prior experience, whether domestic or foreign (Haas 1992; Linos 2007). Experience (as compared to theory) is especially important to the level of confidence actors place in such beliefs. Alan Jacobs' study of the politics of pension reform (this volume and forthcoming) shows that policy-makers were drawn to reforms whose shape resembled schemes with which they were familiar and with a track record on which they could rely. Accordingly, explanations for institutional change must take into account the availability and character of the instrumental beliefs pertinent to the changes under consideration, as well as a range of conditions that might affect the character of those beliefs.

\section{Collective Action Problems, Organization and Power}

Legislative rules are, of course, a special type of institution, whose complexion can often be explained by analyses that assume a world of contracting individuals. Once we move beyond such settings, however, a second set of factors looms larger in processes of institutional change. They are the collective action problems associated with mobilizing actors to take the steps required to enact reform. The magnitude of those problems is 
conditioned, in turn, by the organizational setting within which those who seek or oppose change operate. It deserves to be seen as a core element affecting the likelihood, timing and direction of institutional change.

In the political economy, three types of organizational settings have a direct bearing on institutional change. The organization of the political system (and, in some instances, the internal organization of the state) has a major impact on the types of coalitions that can be assembled in support of institutional reform. Iversen and Soskice (2006) suggest, for instance, that electoral rules condition the viability of coalitions seeking redistribution. The nature of producer group organization affects the capacities of workers and employers to mobilize on behalf of institutional change (Offe and Wiesenthal 1986). Inside firms, the shape of the organizational hierarchy has wellknown effects on the ease with which coalitions can be assembled for various types of institutional change (Teece 1994).

In short, where institutional change depends on the formation of a favorable coalition, analysts cannot neglect collective action dilemmas and the organizational structures that facilitate or impede coalition formation. This observation underlines the role of power relations in institutional change (Moe 2005). Two dimensions of power bear on the likelihood that change will be effected. The first, widely referenced in 
rational choice analyses, is the dimension of power reflected in the relative opportunity costs facing actors contemplating an institutional change. As Knight (1992) notes, actors for whom the opportunity cost of foregoing change are lower will have more power in the accompanying negotiations than actors who would suffer greater losses if the change were not achieved. The second relevant dimension of power is mobilizational, understood as the capacities of the actors to overcome any problems associated with the development of a collective strategy and the mobilization of a constituency in support of that strategy. The latter depends on various types of social resources (McCarthy and Zald 1987).

One of the implications of this point is that the likelihood of institutional change in one direction or another, at any one point in time, is affected by the outcomes of previous episodes of institutional change. The latter leave in place particular organizational forms that intensify or mitigate the collective action dilemmas facing actors interested in institutional change at later points in time. While legislatures can sometimes be modeled as sets of actors contracting with each other on a relatively equal basis, even in democratic polities, capitalist economies do not have this character (Bates 1988). Economies are structured by organized relationships that confer more power to initiate or implement change on some actors than on others. Those at the top of the 
hierarchies constitutive of firms enjoy greater leverage than those at the bottom, and employers often face fewer collective action problems than the workers with whom they are negotiating wages or working conditions (Offe and Wiesenthal 1986).

\section{Distributive Issues and Normative Beliefs}

One of the central, and most plausible, tenets of the rational choice approach holds that actors will agree to institutional reforms only when those reforms make them better off. In several seminal contributions to the literature, Calvert (1995a, b), therefore, models the process of institutional reform as a coordination game, which offers all the parties a better outcome provided they can agree on a new set of institutions. This makes eminent sense. However, as Scharpf (1997) notes, in many real-world settings, the actors face a choice between outcomes that distribute the gains from cooperation differently, even if they make all better off. A classic example is provided by firms considering entering into collaborative arrangements for research and development on a new line of products. All the firms can anticipate gaining from the enterprise, but they have to consider how to apportion the risks associated with it and it may be difficult to do so equally, given that each brings different capacities to the enterprise. Analogous problems arise when firms are negotiating with employees over new work arrangements. 
In such instances, in order to coordinate on new institutions, the actors have to resolve the distributional issue of how to apportion the costs, benefits and risks associated with coordination. Issues of this sort are far from simple. There is evidence, for instance, that actors can be motivated by the relative, as well as the absolute, gains a new set of arrangements offers (Powell 1999). Accordingly, analysts of institutional change need ways of understanding how such distributional issues are resolved.

Part of the answer lies in the dimensions of power that have been described. Those for whom the opportunity costs of foregoing coordination are highest are likely to emerge from the transaction with a smaller share of the gains. Gruber (2000) shows that such considerations played a role in the institutional design of European monetary union. However, this is another issue area to which historical institutionalism brings useful propositions. As Streeck (1997) and others have noted, there is a sociological underlay to most discussions of institutional reform in the political economy. The background against which they are conducted is one in which conventional conceptions of fairness are prominent. Labor organizations are more likely to agree to new institutional arrangements if it can be argued that the benefits flowing from them will be distributed fairly. Even within existing institutional arrangements, coordination becomes more difficult when the results no longer seem 'fair' when judged by prevailing standards. 
In short, even when processes of institutional change are seen predominantly as matters that engage the 'hard-headed' interests of the participants, what we might describe as 'normative beliefs' enter into them. The latter are a critical component of the shared understandings that makes 'common knowledge' and coordination possible (Johnson 1990). In the absence of tacit agreement on such beliefs, the distributional issues associated with coordinating on a new set of institutions are much more difficult to resolve.

Where the establishment of new institutions requires the actors to secure agreement among larger constituencies, such as political parties or trade unions, as it often does, normative beliefs play an even greater role. Normative beliefs can be central to the process whereby the leaders of organizations mobilize consent among their followers. The rank and file will be interested in what they gain from institutional reform but many will also be motivated by a sense of whether the distribution of those gains is just. Claims from social justice are not simply an ideological patina washed over arrangements negotiated for other reasons. They are an intrinsic element of the expectations actors bring to decisions about institutional reform.

\section{Multivariate Preference Functions and Identities}


The effects of institutional change are usually multidimensional and the interests of the actors assembled to support it equally so. A new social policy, for instance, may appeal to trade union leaders because of the organizational resources it offers them, to their rank and file because of the material benefits if provides, and to firms because of the ways it shifts their costs (Palier 2002). But the process of coalition formation underpinning institutional change is further complicated by the fact that each actor involved in the process typically brings to it a multivariate preference function of his own (Hall 2005).

When forming a judgment about the desirability of a proposed institutional reform, trade union leaders may consider, for instance, not only the material benefits it offers their members but the impact of the reform on the union's power vis-à-vis employers, the potential it has for attracting new members, and the resources it provides the union leaders themselves. To reach a decision about whether to support the reform, even when the decision turns entirely on material considerations, the union leaders have to attach implicit weights to each of these types of considerations, namely to variables intrinsic to their preference functions. The executives of firms make equally complex calculations.

Even individuals, whose support may be crucial to a political party's willingness to support or oppose institutional changes, bring multivariate preference functions to such 
issues. Proposals to alter the institutional practices associated with environmental issues, for instance, can bear differently on the roles of the voter as a consumer, worker, parent and citizen, and each voter must decide which of the corresponding concerns to weight more heavily when taking a position on the issue. In this, as in many, cases, those roles are not far removed from the multiple identities voters assume, and the weights each attaches to particular variables in his preference function engaged by the issue may be influenced by which of their identities are engaged most intensely in debates about the issue.

In other words, even if the relevant outcome - understood either as the position taken by an actor or as the institutional result that follows from aggregating those positions - is driven largely by considerations of material interest, issues of identity can be important determinants of the the result. The presumption that identity politics has little to do with the politics of material interest is generally false, and normative beliefs figure prominently in identity politics (cf. Fraser and Honneth 2003). When debates can be configured so as to engage some identities more deeply than others, actors can be induced to join coalitions they might not otherwise support. In this respect, the politics of ideas is intrinsic, rather than epiphenomenal, to the processes of coalition formation that underpin institutional change. 
Network Externalities and Institutional Complementarities

The lively debates among historical institutionalists about 'path dependence' also generate propositions of real value to rationalist accounts of institutional change. The core insight here, with which few rational choice analysts would disagree, is that the impact of any new institutional practice will be mediated by the operation of other institutions unaffected by the reform. When actors form judgments about whether to support a new institutional practice based on calculations about how it will affect them, they take such interaction effects into account. As a result, the character of existing institutions conditions the reception given proposals for institutional reform. The adoption of one set of institutions establishes conditions that make the adoption of others more or less likely, thereby pushing the relevant unit, whether a nation, firm or other organization, along some paths that gradually foreclose others.

Pierson (2000) provides many examples of how such processes of path dependence work, emphasizing the role of increasing returns and network externalities (see also Thelen 1999; Mahoney 2000). Once citizens have adjusted their habits of saving and spending to the establishment of a particular pension regime, for instance, they will be interested in reforms that enhance that regime and reluctant to endorse 
reforms that render those habits unprofitable. If firms respond to the structural inducements present in a national economy to establish specific kinds of production regimes, they will tend to favor reforms that increase the returns from such regimes and to oppose reforms that would require them to adopt entirely new production regimes (Hall and Soskice 2001).

Although an obvious reminder that institutional change does not take place on a tabula rasa, this point offers analysts of institutional change real leverage. It suggests, for instance, that the level of support available from various types of actors for institutional reform in one sphere of the political economy will often be conditioned by the character of existing institutions in other spheres. The explanation Swenson (2001) offers for variation in the attitudes of employers to proposals for 'universalist' pensions in the United States and Sweden provides a masterful example of such processes at work. He argues that the attitudes of employers to proposals for reform of social policy were deeply conditioned by the character of existing institutions in the sphere of wage bargaining. In Sweden, where the strategies of many firms were built on institutional arrangements for industrial relations that limited wage differentials across sectors, the efforts of some firms to attract skilled labor by offering private pensions began to cause discontent among other firms. Universal public pensions provided an attractive way to 
eliminate this practice. By the 1950s, in contrast, American firms had adjusted their strategies to an industrial relations system that promoted segmentalist practices, whereby some firms operated highly efficient production regimes that depended on skilled workers who were attracted by higher wages and benefits, while other firms used less skilled workers to compete on cost. As a result, on both sides of this divide, American employers found the prospect of universal pensions that would undercut such practices unappealing. The extent of employer support for generous universal pensions, therefore, diverged sharply between the two countries as a result of the arrangements developed in each nation for regulating industrial relations.

There would be real value in extending this type of analysis to other issue areas, asking how institutional arrangements in one sphere of the political economy influence proposals for reform in others. In an insightful comparison of France and Germany, for instance, Goyer (2006) finds that the reception firms give to proposals for reform in the sphere of corporate governance is influenced by the character of institutional arrangements in the sphere of labor relations. But there is room for more such inquiries.

\section{A Rationalist Model Expanded}


I have argued that we can deploy some of the core insights generated by historical institutionalism to extend a rationalist model of institutional change. The result is a set of extensions that are analytically manageable and render such models more realistic. In summary, the steps I have suggested are as follows.

i. Begin with the assumption that the precondition for institutional change is often the assembly of a coalition, whether tacit or explicit, in favor of the changes.

ii. Acknowledge not only that uncertainty about the effects of institutional reform is a pillar of institutional stability but that the character of prevailing instrumental beliefs about such effects is a key variable that makes change more or less likely and conditions its direction.

iii. Recognize that, even when institutional change can be secured by reaching agreement among a small set of individuals contracting with each other on a relatively equal basis, assembling coalitions of support for it entails collective action problems whose intensity is affected by the character of existing organizations. And, when we move beyond such settings, issues of power are inescapably bound up with the resolution of such dilemmas. In each of these contexts, the character of existing organizations conditions the relative power of various groups of actors over change as well as its pace and direction. iv. Observe that, even when the process of adopting new institutions can be modeled as a 
coordination game, distributive issues arise. How these issues are resolved then turns on the relative power of the actors (a function of both opportunity costs and mobilizational or strategic capacity) and on normative beliefs about fairness.

$v$. Note that the effects of institutional reform and the preference functions actors bring to proposals for reform are multidimensional, such that the actors' posture toward reform will depend on how each weights the variable in that function. Factors that influence this weighting include those that engage the identities closely associated with the various dimensions in these preference functions. Framing effects, whether born of deliberate or inadvertent processes, emerge as potentially important variables in the processes leading to institutional change.

vi. Observe that the effects of any new set of proposed institutional practices will be mediated by existing institutional practices not targeted for reform, so that the latter become variables conditioning the positions actors take on proposals for institutional reform.

To be sure, this account presents the process whereby institutions change as one that is more complex than some simple models allow. However, one of the striking features of this analysis is that it remains relatively simple and tractable to manageable empirical inquiry. Historical institutionalism is not a cry of despair about the complexity 
of the world. Many of its most important insights can be reduced to testable propositions that greatly enrich our models of institutional change at relatively limited cost in terms of the complexity they add to them.

Moreover, the terms of this account suggest many compatibilities between rationalist and historical approaches to institutional change. One need not abandon a rational choice perspective in order to mobilize many of these insights. They requires only a willingness to accord beliefs, whether instrumental or normative, a role in the relevant processes that is more expansive and precise than the one conveyed by the opaque sphere of 'common knowledge’ to which they are often relegated.

\section{Historical Institutionalism in Sociological Perspective}

There is another side, of course, to the perspective on institutions developed by historical institutionalism. It is well-represented in the chapters of this book, and the rationalist model I have just outlined does not do full justice to it. Although I think rationalist models can explain a good deal of institutional change in many settings, it is important to note what they miss in the world of institutions. I will do so by outlining what I see as some of the core contentions on the sociological side of historical institutionalism. ${ }^{\text {vii }}$ 
At the heart of this alternative approach is a view of institutions themselves that is somewhat different from the one found in rationalist perspectives. The latter tend to stress the rule-like quality of institutions and, by implication, the extent to which institutions are unambiguous and understood in common terms by all the relevant actors. By contrast, although they still see institutions as regularized practices, those with a more sociological leaning tend to stress the intrinsic ambiguity of institutions. Rather than conceptualize them as relatively-sharp rules, they see their underpinnings in norms that are always subject to interpretation and frequently to reinterpretation. In his chapter for this volume, Sheingold stresses the extent to which even Congressional rules are open to creative reinterpretation, and Onoma identifies a 'contradictory potential' in the laws governing land use in Kenya.

This shift in perspective is important because it implies that institutional change need not be contingent on agreement among a coalition of actors or even the explicit object of coalition formation. Instead, it can occur through disaggregated processes of 'reinterpretation' whereby the meanings actors associate with a particular institution change over time with corresponding shifts in patterns of action (Thelen 2005, Streeck and Thelen 2005). Those shifts may be sudden, as some were during the French Revolution, or slow - pushed forward, step by step, by small groups of actors, until one 
pattern of behavior is replaced by another. Reinterpretation of the rules be accompanied by overt contention over issues of interpretation or it may take place in subtle and relatively uncontested steps. When it takes this form, the process is difficult to model as one of coalition formation, and more relevant templates for analysis may lie in sociological studies of 'meaning-making'.

Those with such perspectives also tend to see a world replete with multiple layers of institutions, each with more or less sway over particular actors, many slightly contradictory to others in their implications for behavior, and all constitutive of a broad scaffolding that provides footholds for many courses of action. Institutions are the instruments actors use to negotiate the complexity of the world. In such contexts, far from dictating particular actions, institutions are primarily enabling - structures within which actors exercise a relatively robust agency. Daniel Slater describes the development of dictatorship in Indonesia in precisely these terms.

These perspectives diverge from forms of sociological institutionalism that see institutions as the embodiment of 'logics of appropriateness' and associate their influence with the extent to which they are taken for granted (cf. March and Olsen 1989; Dobbin 1994a). By contrast, historical institutionalists are more inclined to view institutions as the objects of active reinterpretation, and often overt contention, as actors seeking power 
or resources take advantage of their contradictory potential. The persistence of institutions is not a matter of unreflective adherence but the result of exercises of power and interpretation, whose result is at best a contested stability (see the Introduction to this volume).

In common with sociological approaches, however, this perspective emphasizes the extent to which institutions are not simply 'rules' but constituted in equal measure by accompanying rituals and symbol systems. Thus, the fate of an institution can be closely tied to the significance attached to its rituals, whether formal or informal, and conditioned by cultural shifts that see new sets of symbols acquire authority as others fall into desuetude. The affinities with constructivist views prominent in the study of international relations should be apparent (Wendt 2000).

These views of institutions carry important implications for how we should understand processes of institutional change. They lend themselves to images of institutional change quite different from those implicit in rationalist models that focus on the formation of reform coalitions. Some stress that institutions simply break down. Skocpol (1979) proposes a structuralist view of social revolutions, for instance, in which institutions gradually fail as the result of a confluence of separately-determined developments, marked by little in the way of a voluntarist impulse. 
Others suggest that institutions can change as a consequence of processes of 'defection' in which actors gradually stop adhering to the practices formerly constitutive of an institution, whether seriatim or in groups, without any formal agreement to do so (Thelen 2004, see also the Introduction to this volume). Although it may be an exaggeration to claim, as one participant in the workshop discussing the chapters for this volume did, that 'shirkers are the motor of history', there is little doubt that processes such as these are important elements of many instances of institutional change. Thelen and Kume (1999) have shown, for example, that gradual defections from employers associations transformed the operations of the institutions governing wage bargaining in Germany.

Drawing our attention to a third dimension of institutional change, Streeck (2005) has emphasized that many efforts to construct new institutions are experimental, which is to say they proceed in incremental steps, marked by movements backward as well as forward, as new institutions are tried out and then found to be ineffective. He is surely right to draw our attention to the 'experimental' character of some reform processes, whereby institutional change emerges from ad hoc adjustments to standard operating procedures without clear-cut efforts to mobilize coalitions behind those changes, and to emphasize the role of unintended consequences in such processes. Tulia Falleti's chapter 
for this volume traces that kind of process in the case of Brazilian health care; and Palier (2005) argues, based on a study of social security reform in France, that incremental steps of this sort, issuing from negotiations in which the participants rarely agreed even on how to interpret the results of each stage of negotiation, can usher in profound institutional transformation.

There is much to recommend these more sociological perspectives on institutional change. They capture key dimensions of the institutional world, and, although I do not spell them out here, they also supply new research agendas. In particular cases, such formulations may provide a better basis for explaining the pace or direction of change than rationalist perspectives emphasizing coalition formation. At the same time, one can see many points of commonality between the two sides of historical institutionalism. Both accord real importance to the role of ideas in politics. Both see institutions as objects of continuous contention rather than settled arrangements that can be taken for granted, and, behind the operation of institutions, both see the exercise of power.

\section{Conclusion}


Whether undertaken from rationalist or sociological perspectives, the research done by historical institutionalists in recent years has greatly advanced our understanding of institutional change. Scholars working in this intellectual tradition have done more than arguably any other group to develop realistic formulations about how economic and political institutions change over time. As this account implies, they inevitably encounter a tension between a requirement to develop the relatively-simple models that form the substance of social science and the need to portray the real world in realistic terms. But, on my reading, they have managed this tension with considerable success. The result is a set of formulations that provide the basis for research agendas with great promise.

There are many issues on those agendas still to be resolved. We do not yet know how the process of institutional change varies across issue domains or spheres of the polity. In some, change may be typically slow or incremental, and, in others, more frequent or abrupt. We could benefit from more investigation into the sources of innovation. In principle, agents facing intense processes of competitive selection, as most democratic governments and firms do, may be more likely to innovate than organized agents who are sheltered from such processes. There is also more to be learned from comparison between cases of institutional stability and cases of change. Thelen (2004) has shown how changes in some dimensions of the institutional setting make 
continuity possible in other dimensions, but we need more general accounts of such processes, built on further case-studies and more intensive dialogue with analysts of organizational change (cf. McCarthy and Zald 1987).

My bet is that the greatest advances will be made by those willing to borrow concepts and formulations from multiple schools of thought. That is why I have emphasized the points of tangency between rational choice and historical institutionalism and dwelt at some length on the insights available from more sociological perspectives. There is much to be said for analyses that take the opposite tack, i.e. those that dwell on the differences between schools of thought. That kind of analysis tends to throw the inadequacies of each theoretical approach into sharp relief, thereby stimulating improvement. Without irritants, there would be no pearls. However, if there is insight in all of these approaches, as I believe, it seems short-sighted to cling to one at the expense of benefiting from the others. In many cases, the propositions of each can be tested against one another. I have argued that it is often possible to construct synthetic models, whose component parts are eminently testable. In many instances, substantial additional insight can be purchased at a relatively small loss in terms of analytical parsimony. With respect to issues of institutional change, fruitful synthesis is surely the most promising way forward and, positioned as it is between rationalist and sociological views, historical 
institutionalism is ideally placed to take those steps forward. 


\section{REFERENCES}

Bates, Robert. 1988. “Contra Contractarianism: Some Reflections on the New Institutionalism,” Politics and Society 16 (2): 387-401.

Calvert, Randall. 1995a. "Rational Actors, Equilibrium and Institutions.” In Jack Knight and Iai Sened, eds., Explaining Social Institutions. Ann Arbor: University of Michigan Press: 57-94.

Calvert, Randall. 1995b. "The Rational Choice Theory of Institutions: Cooperation, Coordination and Communication.” In Jeffrey S. Banks and Eric A. Hanuschek, eds., Modern Political Economy. New York: Cambridge University Press: 216-68.

Campbell, John A. 2004. Institutional Change and Globalization. Princeton: Princeton University Press.

Dobbin, Frank. 1994a. Forging Industrial Policy: The United States, Britain and France in the Railway Age. New York: Cambridge University Press.

Dobbin, Frank. 1994b. "Cultural Models of Organization: The Social Construction of Rational Organizing Principles.” In Diana Crane, ed., The Sociology of Culture. Oxford: Blackwell: 117-91.

Fraser, Nancy and Axel Honneth. 2003. Recognition or Redistribution? A PoliticalPhilosophical Exchange. London: Verso Books. 
Goldstein, Judith and Robert Keohane. 1993. Eds. Ideas and Foreign Policy. Ithaca: Cornell University Press.

Goyer, Michel. 2006 “The Transformation of Corporate Governance in France.” In Pepper Culpepper, Peter A. Hall, and Bruno Palier. Eds. Changing France: The Politics that Markets Make. London: Palgrave-Macmillan:

Greif, Avner and David Laitin. 2004. "A Theory of Endogenous Institutional Change,” American Political Science Review, 98: 622-562.

Gruber, Lloyd. 2000. Ruling the World: Power Politics and the Rise of Supranational Institutions. Princeton: Princeton University Press.

Haas, Peter. 1992. Introduction: Epistemic Communities and International Policy Coordination,“ International Organization 46, 1 (Winter):

Hall, Peter A. 1989. ed., The Political Power of Economic Ideas: Keynesianism across Nations. Princeton: Princeton University Press.

Hall, Peter A. 2005. "Preference Formation as a Political Process: The Case of Monetary Union in Europe.” In Ira Katznelson and Barry Weingast, eds., Preferences over Time. New York: Russell Sage Foundation.

Hall, Peter A. and David Soskice. 2001. eds., Varieties of Capitalism: The Institutional Foundations of Comparative Advantage. Oxford: Oxford University Press. 
Hall, Peter A. and Rosemary CR Taylor. 1996. "Political Science and the Three 'New Institutionalisms'," Political Studies (December): 936-57.

Iversen, Torben and David Soskice. 2006. Electoral Institutions and the Politics of Coalitions: Why Some Democracies Redistribute More than Others,“ American Political Science Review 100 (2): 165-181.

Jacobs, Alan. Forthcoming. How do Ideas Matter? Mental Models and Attention in German Pension Politics,“ Comparative Political Studies.

Johnson, James. 1990. On the Cultural Dimensions of Rational Choice Theory.“ Paper presented to the Mid-West Political Science Association.

Knight, Jack. 1992. Institutions and Social Conflict. New York: Cambridge University Press.

Knight, Jack. 1995. "Models, Interpretation and Theories: Constructing Explanations of Institutional Emergence and Change.” In Jack Knight and Iai Sened, eds., Explaining Social Institutions. Ann Arbor: University of Michigan Press: 95-120.

Koremenos, Barbara, Charles Lipson and Duncan Snidal. 2003. eds. The Rational Design of International Institutions. New York: Cambridge University Press. Krehbiel, Keith. 1991. Information and Legislative Organization. Ann Arbor: University of Michigan Press. 
Linos, Katerina. 2007. Diffusion of Social Policies across OECD Countries. Doctoral Dissertation, Department of Government, Harvard University. MacIntyre, Alasdair. 1978. “Is a Science of Comparative Politics Possible?” in Paul Lewis et al., eds., The Practice of Comparative Politics. New York: Longman. Mahoney, James. 2000. “Path Dependence in Historical Sociology,” Theory and Society 29: 507-48.

March, James G. and Johan P. Olsen. 1989. Rediscovering Institutions: The Organizational Basis of Politics. New York: Free Press.

Marshall, William J. and Barry R. Weingast. 1988. The Industrial Organization of Congress, or Why Legislatures, Like Firms, Are Not Organized as Markets,“ Journal of Political Economy, 96, 1 (February): 132-63.

McCarthy, John D. and Meyer N. Zald. 1987. Social Movements in an Organizational Society: Collected Essays. New York: Transaction Publishers.

McNamara, Katherine. 1998. The Currency of Ideas. Ithaca: Cornell University Press. Moe, Terry. 2005. “Power and Political Institutions,” Perspectives on Politics 3, 2 (June): 215-234.

Offe, Claus and Helmut Wiesenthal. 1986. "Two Logics of Collective Action: Theoretical Notes on Social Class and Political Form”.In Claus Offe, Disorganized 
Capitalism. Cambridge: MIT Press.

Palier, Bruno. 2002. Gouverner la Sécurité Sociale. Paris: Presses Universitaires de France.

Palier, Bruno. 2005. “Ambiguous Agreement, Cumulative Change: French Social Policy

in the 1990s. In Wolfgang Streeck and Kathleen Thelen, eds., Beyond Continuity:

Institutional Change in Advanced Political Economies. Oxford: Oxford University Press: $127-144$.

Pierson, Paul. 2000a. "Increasing Returns, Path Dependence and the Study of Politics," American Political Science Review 94, 2:

Powell, Robert. 1999. In the Shadow of Power: States and Strategies in International Politics. Princeton: Princeton University Press.

Riker, William. 1980. Implications from the Disequilibrium of Majority Rule for the Study of Institutions,“ American Political Science Review 74, 2: 432-46..

Sabel, Charles and Jonathan Zeitlin. 1997. World of Possibilities: Flexibility and Mass

Production in Western Industrialization . New York: Cambridge University Press.

Scharpf, Fritz. 1997. Games Real Actors Play. Boulder: Westview.

Shepsle, Kenneth. 1989. “Studying Institutions: Some Lessons from the Rational Choice Approach,” Journal of Theoretical Politics, 1: 131-49. 
Shepsle, Kenneth. 1986. "Institutional Equilibrium and Equilibrium Institutions.” In Herbert Weisberg, ed., Political Science: The Science of Politics. New York: Agathon: $51-81$.

Skocpol, Theda. 1979. States and Social Revolutions. New York: Cambridge University Press.

Steinmo, Sven, Kathleen Thelen and Frank Longstreth. 1992. Eds. Structuring Politics. New York: Cambridge University Press.

Streeck, Wolfgang. 1997. "The German Economic Model: Does it Exist? Can it Survive?" in Crouch and Streeck, eds., The Political Economy of Modern Capitalism London: Sage.

Streeck, Wolfgang. 2005. “Rejoinder: On Terminology, Functionalism, (Historical) Institutionalism and Liberalism,” Socio-Economic Review 3: 577-87.

Streeck, Wolfgang and Kathleen Thelen. 2005. eds. Beyond Continuity: Institutional Change in Advanced Political Economies. Oxford: Oxford University Press.

Swenson, Peter, 2001. Capitalists Against Markets. New York: Oxford University Press.

Teece, David J. 1996. ”Firm Organization, Industrial Structure and Technological Innovation,“ Journal of Economic Behavior and Organization 31, 2 (November): 193- 
224.

Thelen, Kathleen. 1999. "Historical Institutionalism in Comparative Politics,” Annual Review of Political Science 2: 369-404.

Thelen, Kathleen 2004. How Institutions Evolve. New York: Cambridge University Press. Thelen, Kathleen and Ikuo Kume. 1999. "The Effects of Globalization on Labor

Revisited: Lessons from Germany and Japan," Politics and Society 27 (December): 477505.

Wendt, Alexander. 2000. Social Theory of International Politics. New York: Cambridge University Press. 


\section{NOTES}

${ }^{\mathrm{i}}$ Representative works and reviews include: Steinmo et al. 1992; Knight 1992; Campbell 2004; Hall and Taylor 1996

ii For influential recent works, see: Thelen 2004, Streeck and Thelen 2005; Swenson 2001, Greif and Laitin 2004.

${ }^{\text {iii }}$ For thoughtful analyses that have long been skeptical of institutional analysis on such grounds, see Sabel and Zeitlin 1997.

iv See also Thelen 2004: Introduction. For notable efforts to address this problem from within a rational choice perspective, see Knight 1992; Calvert 1995b, Gruber 2000 and Greif and Laitin 2004.

${ }^{\mathrm{v}}$ For an alternate perspective, see the second part of this chapter.

${ }^{\text {vi }}$ See the chapter by Adam Sheingate in this volume for an argument that this stability should not be overstated.

${ }^{\text {vii }}$ For another account, complementary to this one, see the Introduction to this book. 